\title{
Effective prevention of cardiovascular diseases improves quality of life
}

\section{Edhem Kobilić*1, Elnur Smajić ${ }^{2}$}

'Foundation "Bosanska Bašta", Bosnia and Herzegovina

${ }^{2}$ Public Health Institution University Clinical Cente Tuzla, Tuzla, Bosnia and Herzegovina
KEYWORDS: prevention, quality of life, recreational medicine.

CITATION: Cardiol Croat. 2016;11(10-11):499. | DOI: http://dx.doi.org/10.15836/ccar2016.499

*ADDRESS FOR CORRESPONDENCE: Edhem Kobilić, Via Rodreè 6, 6900 Massagno/Lugano, Switzerland.

Phone: +4191-9210518 / E-mail: edokobilic@hotmail.com

ORCID: Edhem Kobilić, http://orcid.org/0000-0002-8543-905X • Elnur Smajić, http://orcid.org/0000-0003-0881-9443

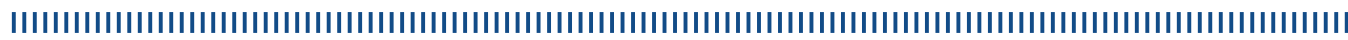

therosclerosis is progressive disease. Changes in arterial blood vessels, with the process of formation of atherosclerotic Aplaques, are substrates on which consequently arise various forms of vascular changes. The fight against atherosclerosis must be directed to change course of disease, against risk factors responsible for speeding up the process of atherosclerosis Current models of prevention are not reduce the prevalence of risk factors - epidemic lasts. It is necessary to change the concept that have failed..$^{1-3}$

Critical analysis opposes two concepts. The old one, unites necessary actions to bring the patient in better physical, psychological and social conditions, to take over the achieved position in society with active life. The modern one focuses on quality of life by:

helping and motivating patients:

to change lifestyles

fighting the influence of risk factors

the final effect is an improvement of the prognosis. ${ }^{4}$

It starts from the active relationship of the individual to their own health and the adoption of personal responsibility, with economical aspects. It is sports recreation - personal activity on health improvement. Motivation of patient, can stimulate one who does know how to explain all details related to the causes of pathological condition and possible treatment options. This task can be performed by a cardiologist, or a specialist of sports or recreational medicine.

The marathon distance is between the need for a change in lifestyle to realization of reeducation and the adoption of positive behavior styles. The best place for it is counselling. The prevention of cardiovascular diseases ideally begins during pregnancy and lasts for life, but is most effective in children and adolescents. It is more effective than pharmacological treatment, and brings enormous economic benefits. The gap between scientific findings and implementation in clinical practice is big.

The modern concept is the complex one, changing lifestyles and eliminating risk factors, one can preserve and improve health. It is necessary, that new health profiles and efforts to develop the initial structure to the end. Recreational medicine needs to establish itself in an area that belongs in it.
RECEIVED:

October 3, 2016

ACCEPTED:

October 10, 2016

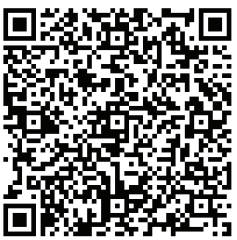

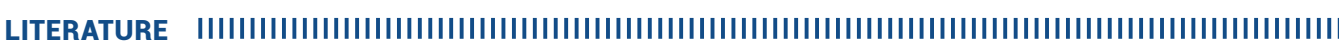

1. Authors/Task Force Members, Piepoli MF, Hoes AW, Agewall S, Albus C, Brotons C, Catapano AL, et al. 2016 European Guidelines on cardiovascular disease prevention in clinical practice: The Sixth Joint Task Force of the European Society of Cardiology and Other Societies on Cardiovascular Disease Prevention in Clinical Practice (constituted by representatives of 10 societies and by invited experts): Developed with the special contribution of the European Association for Cardiovascular Prevention \& Rehabilitation (EACPR). Eur J Prev Cardiol. 2016;23(11):NP1-NP96. DOI: http://dx.doi.org/10.1177/2047487316653709

2. World Health Organization. The world health report 2002 - reducing risk, promoting healthy life. Avalable at: http://www.who.int/whr/2002/en/ (20.9. 2016).

3. European Heart Network and European Society of Cardiology. European Cardiovascular Disease Statistics 2012 edition. Available at: https://www.escardio.org/static_file/Escardio/Press-media/press-releases/2013/EU-cardiovascular-disease-statistics-2012.pdf (20. 9. 2016).

4. Kobilić E. Zamor i prevencija zamora - PAO u mikropauzama (specijalistički rad). Medicinski fakultet Beograd, 1990;7-9. 